University of Nebraska - Lincoln

DigitalCommons@University of Nebraska - Lincoln

\title{
BEHAVIOR AND REPRODUCTIVE SUCCESS OF ROCK SANDPIPERS BREEDING ON THE YUKON-KUSKOKWIM RIVER DELTA, ALASKA
}

\author{
Matthew Johnson \\ U.S. Geological Survey, matthew_johnson@usgs.gov \\ Jesse R. Conklin \\ Massey University \\ Branden L. Johnson \\ U.S. Geological Survey \\ Brian J. McCaffery \\ U.S. Fish and Wildlife Service \\ Susan M. Haig \\ U.S. Geological Survey, Susan_Haig@usgs.gov \\ See next page for additional authors
}

Follow this and additional works at: https://digitalcommons.unl.edu/usgsstaffpub

Johnson, Matthew; Conklin, Jesse R.; Johnson, Branden L.; McCaffery, Brian J.; Haig, Susan M.; and Walters, Jeffrey R., "BEHAVIOR AND REPRODUCTIVE SUCCESS OF ROCK SANDPIPERS BREEDING ON THE YUKON-KUSKOKWIM RIVER DELTA, ALASKA" (2009). USGS Staff -- Published Research. 695. https://digitalcommons.unl.edu/usgsstaffpub/695

This Article is brought to you for free and open access by the US Geological Survey at DigitalCommons@University of Nebraska - Lincoln. It has been accepted for inclusion in USGS Staff -- Published Research by an authorized administrator of DigitalCommons@University of Nebraska - Lincoln. 


\section{Authors}

Matthew Johnson, Jesse R. Conklin, Branden L. Johnson, Brian J. McCaffery, Susan M. Haig, and Jeffrey R. Walters 


\title{
BEHAVIOR AND REPRODUCTIVE SUCCESS OF ROCK SANDPIPERS BREEDING ON THE YUKON-KUSKOKWIM RIVER DELTA, ALASKA
}

\author{
MATTHEW JOHNSON, $, 1,5$ JESSE R. CONKLIN, ${ }^{2}$ BRANDEN L. JOHNSON, ${ }^{1}$ \\ BRIAN J. MCCAFFERY, ${ }^{3}$ SUSAN M. HAIG, ${ }^{1}$ AND JEFFREY R. WALTERS ${ }^{4}$
}

\begin{abstract}
We studied Rock Sandpiper (Calidris ptilocnemis) breeding behavior and monitored reproductive success from 1998 to 2005 on the Yukon-Kuskokwim River Delta, Alaska, USA. We banded 24 adults and monitored 45 nests. Annual return rate of adults ranged between 67 and 100\%. Six pairs of Rock Sandpipers bred at our study site for $\geq 2$ years, and among these we did not observe mate change (i.e., when both members of a pair returned and each mated with a new individual). Nests were typically initiated by mid-May and 53\% of females laid second clutches if first clutches were lost through mid-June. Males regularly incubated clutches during the morning (0800-1259 hrs AKDT) and afternoon (1300-1759 hrs) and rarely during the evening (1800$2300 \mathrm{hrs}$ ), whereas female incubation was relatively consistent throughout the day. Apparent nest success (percent of known nests successfully hatching $>1$ chick) among first and second nests was 19 and 44\%, respectively $(n=45)$. A minimum of $44 \%$ of hatching nests fledged at least one young. Males cared for young but half of females deserted mate and brood 1-7 days post-hatch. This first description of North American Rock Sandpiper breeding behavior from a color-marked population complements previous work on this species on the Chukotsky Peninsula, Russia. Received 21 January 2008. Accepted 30 August 2008.
\end{abstract}

The Rock Sandpiper (Calidris ptilocnemis) is one of the most polytypic shorebird species in the family Scolopacidae (Charadriiformes) and has one of the most northerly nonbreeding distributions of all shorebirds. It is the only breeding species endemic to Beringia with recognized subspecies (AOU 1957) and is generally considered to form a superspecies with Purple Sandpiper (C. maritima) of the north Atlantic (Conover 1944, Cramp and Simmons 1983, Sibley and Monroe 1990). Rock Sandpipers are distinct among North American shorebird species as they exhibit an intraspecific leapfrog migration pattern (Boland 1990). C. p. quarta and C. p. couesi are essentially sedentary with the latter undertaking temporary movements in response to harsh climatic conditions (Fig. 1, Gill et al. 2002). C. p. ptilocnemis is a short- to inter-

${ }^{1}$ U.S. Geological Survey, Forest and Rangeland Ecosystem Science Center, 3200 SW Jefferson Way, Corvallis, OR 97331, USA.

${ }^{2}$ Department of Ecology, Massey University, Palmerston North, New Zealand.

${ }^{3}$ U.S. Fish and Wildlife Service, Yukon Delta National Wildlife Refuge, P. O. Box 346, Bethel, AK 99559, USA.

${ }^{4}$ Department of Biological Sciences, Virginia Polytechnic Institute and State University, Blacksburg, VA 24061, USA.

${ }^{5}$ Corresponding author; e-mail: matthew_johnson@usgs.gov mediate-distance migrant that moves between breeding sites on Bering Sea islands and nonbreeding sites in upper Cook Inlet and, to a lesser extent, along other shorelines from the Alaska Peninsula south to the Alexander Archipelago (Gill and Tibbitts 1999, Gill et al. 2002). In contrast, some populations of $C . p$. tschuktschorum undertake annual round-trip flights of 7,000 km (Gill et al. 2002). However, understanding timing of migration and specific routes is complicated by subspecies having partially sympatric molting and wintering areas (Gill et al. 2002).

There have been few studies of Rock Sandpiper breeding behavior in North America (Hanna 1921, Miller 1996, Gill et al. 2002, Johnson and McCaffery 2004), and none with colormarked individuals. Previous work focused on subspecific classification and distribution, postbreeding and winter ecology, and feeding (Preble and McAtee 1923, Smith 1952, Gill and Jorgensen 1979, Gill and Handel 1990, Gill 1997, Gill and Tibbitts 1999, Gill et al. 2002, Pruett and Winker 2005). Bent (1927) summarized descriptions of breeding behavior of Rock Sandpipers from 19th century explorers, and Hanna (1921) provided early accounts of breeding behavior for C. p. ptilocnemis. Breeding behavior of color-marked individuals has only been studied for C. p. tschuktschorum on the Chukotsky Peninsula, Russia (Kondratyev 1982; Tomkov- 


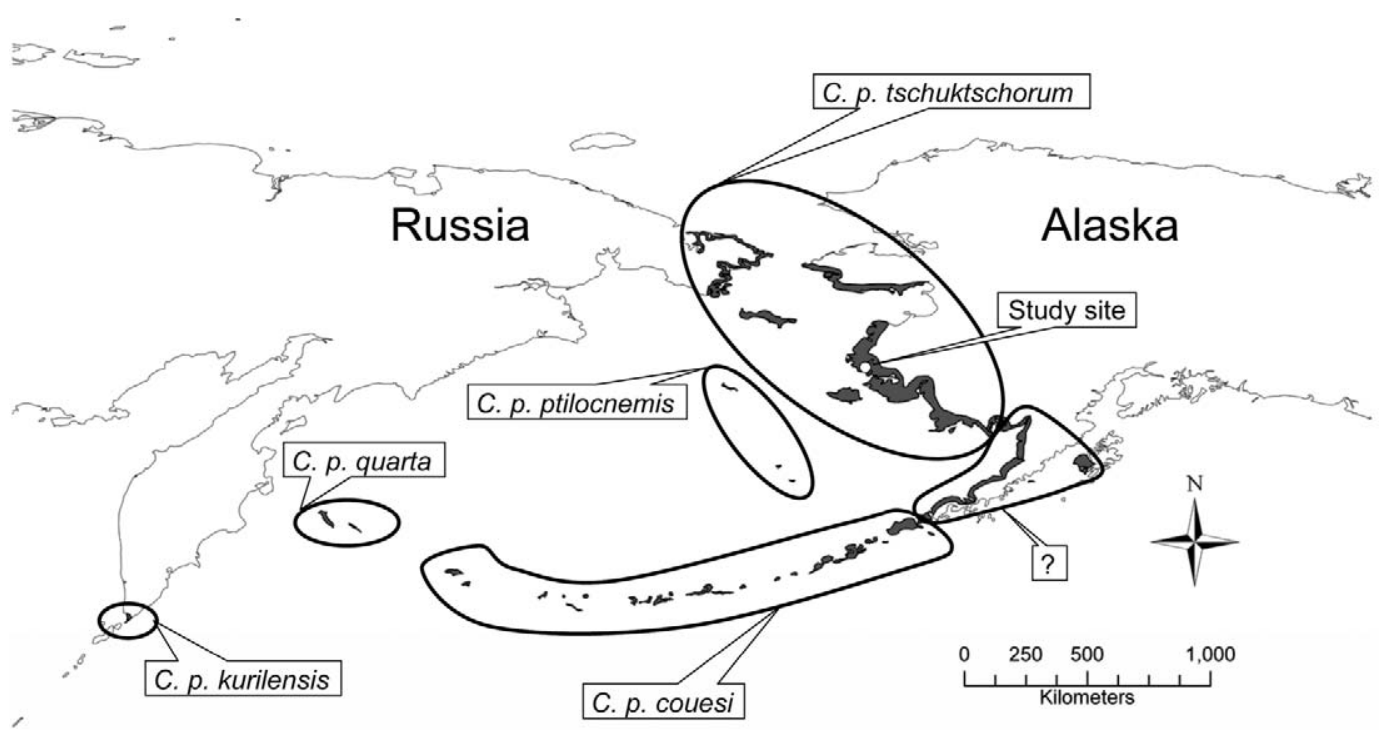

FIG. 1. Subspecific breeding distribution of the Rock Sandpiper (Calidris ptilocnemis) and location of the study site (Yukon Delta National Wildlife Refuge's Kanaryarmiut Field Station, Yukon-Kuskokwim River Delta, Alaska). Evidence for subspecific status of Rock Sandpipers on Alaska Peninsula, upper Bristol Bay, and Kodiak Archipelago is equivocal (area labeled with a question mark). C. p. kurilensis is a provisional subspecies that has a probable breeding distribution of a $15-\mathrm{km}$ stretch of beach on the southern tip of the Kamchatka Peninsula (Gill et al. 2002).

ich 1994, 2003). Males in this population established and defended territories on upland tundra habitat from which they advertised for mates (Myers et al. 1982; Tomkovich 1985, 1994). Nests were initiated from mid-May through mid-June (P. S. Tomkovich in Gill et al. 2002), and some pairs initiated replacement clutches if nest loss occurred early in the season (Tomkovich 1994, 2003). Rock Sandpipers were socially monogamous and commonly exhibited biparental care of eggs and young. However, one member of the pair, usually the female, deserted its mate and brood shortly after hatch, or rarely, even before hatch (Myers et al. 1982; Tomkovich 1994, 2003).

The Rock Sandpiper is listed as a species of high concern in the U.S. Shorebird Conservation Plan (Brown et al. 2001, USSCP 2004) due to restricted breeding distribution, limited population size (Morrison et al. 2006), and threats to nonbreeding sites (Gill and Tibbitts 1999). Thus, identifying the extent of variation in life history and behavior among/ within subspecies is critical for effective conservation, yet this has not been reported from North America, where three of the four subspecies occur. Our objectives were to: (1) de- scribe breeding phenology and habitat use; (2) measure mate and breeding site fidelity rates; (3) quantify hatching and fledging success, and parental care in a color-marked breeding population on the Yukon-Kuskokwim River Delta, Alaska; and (4) compare our results with those from studies $600 \mathrm{~km}$ west in Chukotka, Russia.

\section{METHODS}

Study Area and General Methods.-Our study area was at the Yukon Delta National Wildlife Refuge's Kanaryarmiut Field Station, Yukon-Kuskokwim River Delta (YKD), Alaska (Fig. 1; 61 $22^{\prime} \mathrm{N}, 165^{\circ} 07^{\prime} \mathrm{W}$ ). We located and monitored Rock Sandpiper nests opportunistically during 1998-2002 on and around a 36-ha plot while gathering data for other avian studies (mean \pm SD number nests located annually $=4.0 \pm 1.6,4$ adults banded). We systematically studied Rock Sandpipers during 2003-2005 (mean \pm SD number nests located annually $=10.7 \pm 1.5,20$ adults banded), monitoring nests and recording individual behavior on an additional 12 ha surrounding the original plot (48 ha total).

Two to four observers surveyed daily for 
banded birds, nests, and broods from late April through late July (2003-2005). We marked adults and chicks at the nest with a U.S. Geological Survey federal bird band and with unique combinations of UV-stable color bands. We measured morphological features during banding including: mass; length of closed, flattened wing (Stiles and Altshuler 2004); exposed culmen (Baldwin et al. 1931); and total tarsus (including lateral condyle of tibiotarsus). We assigned gender of adults by culmen length. Female Rock Sandpipers average larger than males in all measurements, but culmen length overlaps between males and females (males: range $=23.1-30.8 \mathrm{~mm}$; females: range $=28.1-34.0 \mathrm{~mm}$; Tomkovich 1982, Gill et al. 2002). When culmen length was inconclusive (28.1-30.8 mm, 30\% of females, $60 \%$ of males), we assigned gender by comparing culmen length and mass with their mates (females $>$ males) and/or behavior (courtship displays, copulation position).

We mapped locations of banded individuals (2003-2005) and nests (2000-2005) using ArcMAP GIS software (ESRI, Redlands, CA, USA). We produced vegetation maps in the field by manually delineating vegetation patches on aerial photographs, and digitized and geo-referenced habitat polygons using ArcMAP. The upland tundra vegetation community was a mosaic of patches which we classified into three basic types: (1) upland tundra that contained graminoid species (hereafter tundra-grass); (2) upland tundra that lacked a graminoid component (hereafter tundra); and (3) undulating-tundra, characterized by greater vertical relief that resulted in retention of water for longer periods after spring thaw as well as a sedge and grass component (Johnson and McCaffery 2004, Johnson 2006). We monitored nests until hatch, predation, or abandonment. We attempted to reobserve sandpiper parents and broods daily after hatch until their fate was learned (in each case, brood location was mapped, and parent and chick behaviors were recorded using scan sampling [Altmann 1974]). We categorized parental behavior as brooding, vigilant toward the brood (parent was engaged in vigilance behavior toward the brood), or not vigilant (when a parent engaged in some other activity; e.g., foraging). We categorized maximum distance between parents and chicks as $<1,1-$
$3,4-6,7-9,10-20$, or $>20 \mathrm{~m}$. We quantified linear distance traveled by broods as the straight-line distance between two observations (i.e., first and last observations of the day, week, or brood care period). Nests hatching $\geq 1 \mathrm{egg}$, and broods fledging $\geq 1$ young were considered successful.

Data Analyses.-We overlaid nest locations on our vegetation map to examine habitat use, and used Chi-square goodness of fit to test if birds nested in each habitat type in proportion to availability (Zar 1999). We were able to identify which adult was incubating from nest observations, and randomly selected one observation per individual/nest and used a contingency table to test whether temporal incubation pattern was independent of gender (Zar 1999). We used the mid-point of each distance class $(<1=0.5 \mathrm{~m}, 1-3=2 \mathrm{~m}, 4-6=5 \mathrm{~m}$, $7-9=8 \mathrm{~m}, 10-20=15 \mathrm{~m},>20=25 \mathrm{~m})$, and simple linear correlation to measure whether the distance between parents and chicks varied throughout brood care (Zar 1999). Estimating Rock Sandpiper home range size was problematic. Rock Sandpipers foraged extensively off territory during the breeding season, using habitat beyond our study plot. Small sample sizes prohibited use of the most accurate home range estimation methods currently available (e.g., kernel methods, Seaman et al. 1999). However, there are no published estimates of Rock Sandpiper home range size from North America and we produced coarse estimates of home range size where data were sufficient (2004-2005, $n=$ 329 locations). We selected individuals for this analysis with $>10$ observations/year with a minimum of $4 \mathrm{hrs}$ between consecutive observations. This process resulted in selection of five males and three females over a 2-year period with a mean of 14 observations/individual. We used these data to produce estimates of home range size by drawing minimum convex polygons around the location of individuals (Mohr 1947). We used a Wilcoxon two-sample test to compare linear measurements and mass between adult males and females (Zar 1999). We report apparent nest success (percent of known nests successfully hatching $\geq 1$ chick) and also calculated daily survival rate of nests ( \pm SE) using the Mayfield method (Mayfield 1961, 1975). We compared our estimate of nest daily survival rate 
TABLE 1. Data for Rock Sandpipers on a 48-ha plot near the Yukon Delta National Wildlife Refuge's Kanaryarmiut Field Station, Yukon-Kuskokwim River Delta, Alaska. Numbers in parentheses indicate number of nests hatching at least one egg.

\begin{tabular}{|c|c|c|c|c|c|c|}
\hline \multirow[b]{2}{*}{ Year } & \multirow{2}{*}{$\begin{array}{c}\text { Birds } \\
\text { banded }\end{array}$} & \multirow{2}{*}{$\begin{array}{l}\text { Nests } \\
\text { located }\end{array}$} & \multicolumn{3}{|c|}{ Nests } & \multirow{2}{*}{$\begin{array}{l}\text { No } \\
\text { nest } \\
\text { data }\end{array}$} \\
\hline & & & First & Second & Unknown & \\
\hline 1998 & 0 & $3(0)$ & & & $1(0)$ & 2 \\
\hline 1999 & 3 & $4(1)$ & $1(1)$ & & $3(0)$ & \\
\hline 2000 & 1 & $6(1)$ & $2(1)$ & $1(0)$ & $3(0)$ & \\
\hline 2001 & 0 & $5(0)$ & $1(0)$ & & $4(0)$ & \\
\hline 2002 & 0 & $2(0)$ & & & & 2 \\
\hline 2003 & 10 & 11 (2) & $5(0)$ & $2(2)$ & $2(0)$ & 2 \\
\hline 2004 & 3 & $9(3)$ & $5(1)$ & $3(1)$ & 1 (1) & \\
\hline 2005 & 7 & $12(2)$ & 7 (1) & $3(1)$ & $1(0)$ & 1 \\
\hline Totals & 24 & $52(9)$ & $21(4)$ & 9 (4) & $15(1)$ & 7 \\
\hline
\end{tabular}

with a previously reported estimate from Chukotka, Russia using a $Z$ statistic (Johnson 1979), and report means ( \pm SD).

\section{RESULTS}

Rock Sandpipers arrived at our study site between 21 April and 10 May annually (mean arrival date = 1 May). Males began establishing territories and advertising for mates during the first week of May. We banded four adults from three pairs in 1999 and 2000 and uniquely color banded 24 breeding adults through 2005 (Table 1). A pair banded in 1999 returned and bred together every year thereafter through 2005, but the other two individuals banded during this period were not observed in subsequent seasons. We banded five breeding pairs in 2003. All 10 of these birds were observed at the study site in 2004, and seven returned in 2005 . We banded three adults from two pairs in 2004, and observed two of these birds in 2005 . We banded 8 and 10 chicks in 2003 and 2004, respectively. These 18 birds were not observed during subsequent seasons. Females were generally larger than males for all morphological measurements except tarsus length, and there was overlap between males and females in all measurements except culmen length (Table 2).

Mate Fidelity.-We did not observe mate change (i.e., both members of a pair returned and each mated with a new individual) among six pairs of Rock Sandpipers that bred at our study site for $\geq 2$ years. However, we observed two males paired with new mates when their mate from the previous year was apparently unavailable. A male bred with the same female in 2003 and 2004, but was paired with an unmarked female in 2005 . We failed to detect his prior mate in 2005. A different pair bred for 2 consecutive years, both returned during the third season, but the female was found partially consumed early in the season, and the male eventually paired with an unmarked female.

Clutch Size and Breeding Phenology.-We discovered 52 active nests between 4 May and 10 July 1998-2005. Of these, 21 nests were first nesting attempts of the season and nine were second nesting attempts (i.e., renestings). We were unable to ascertain which nest attempt was observed in 15 cases because either the attending adults were unbanded or because the nests were found late in the season. We did not monitor seven nests because of logistic constraints (Table 1). Among completed clutches, $88 \%$ contained four eggs $(n=40)$. Mean clutch size for first and second nests were $3.9 \pm 0.4 \mathrm{eggs}(n=20)$ and $3.8 \pm 0.7$ eggs $(n=8)$, respectively, and mean clutch size for all other nests was $3.8 \pm 0.5$ eggs $(n$ $=12$ ). We discovered eight nests on the day they were initiated and another 24 nests prior to completion. On average, females added an egg to clutches every $1.1 \pm 0.2$ days $(n=32)$ until they were completed. We therefore subtracted 1 day for every egg present in the nest at discovery to estimate initiation date for incomplete clutches located after initiation.

TABLE 2. Linear measurements $(\mathrm{mm})$ and mass $(\mathrm{g})$ (mean $\pm \mathrm{SD}$, range) of adult male $(n=10)$ and female $(n=10)$ Rock Sandpipers near the Yukon Delta National Wildlife Refuge's Kanaryarmiut Field Station, YukonKuskokwim River Delta, Alaska. Asterisks indicate differences between males and females at $P<0.01$ (Wilcoxon two-sample tests).

\begin{tabular}{lcccc}
\hline Gender & Culmen* & Tarsus & Wing* & Mass* \\
\hline Female & $32.8 \pm 1.9(29.9-34.5)$ & $28.2 \pm 1.3(26.5-30.0)$ & $129.0 \pm 2.8(126-132)$ & $85.6 \pm 2.4(73-89)$ \\
Male & $27.4 \pm 0.7(26.8-29.6)$ & $28.3 \pm 1.1(27.1-29.6)$ & $125.2 \pm 2.1(123-133)$ & $76.4 \pm 5.1(70-84)$ \\
\hline
\end{tabular}


Mean clutch initiation date for first nests was 16 May \pm 9 days (range 5 May-7 Jun, $n=$ 18). Fifteen of 17 first nests (2003-2005) were depredated; 8 of these 15 females (53\%) produced replacement clutches. Mean clutch initiation date for renesting attempts was 27 May \pm 8 days (range 20 May-11 Jun, $n=7$ ). Mean clutch initiation date for nests where we were unable to learn whether this represented the pairs' first or second nesting attempt was 7 June \pm 8 days (range 23 May-16 Jun; $n=$ 7). Mean incubation length (clutch initiation through hatch) was $26.3 \pm 0.8$ days $(n=7)$.

Hatching and Fledging Success.-Apparent nest success among first and second nests was 19 and 44\%, respectively (Table 1). Apparent nest success was $20 \%$ when we considered all nests with known fates $(n=45)$. Seven nests had insufficient data for inclusion in daily survival rate estimation. Mayfield nest success rate for all nests with sufficient data was $25 \%$ (584.5 nest exposure days, 30 failed nests, $n$ $=38)$, and daily nest survival rate $(0.949 \pm$ 0.001 ) was significantly lower than reported for Rock Sandpipers breeding on the Chukotsky Peninsula $(0.974 \pm 0.001 ; Z=2.14, n=$ $79, P=0.02)$. All but one of 35 eggs in successful nests hatched. One nest was abandoned, and predation is suspected as the cause for failure of all other failed nests $(n=35)$. We observed mink (Mustela vison) and Arctic fox (Alopex lagopus) depredating nests. We also observed a Long-tailed Jaeger (Stercorarius longicaudus) consuming 12 day-old chicks from one brood. At least four broods (44\%) among the nine successful nests successfully fledged young, two broods failed to fledge any young, and three broods had unknown fates. We were unable to monitor two successful broods as they moved out of our study area, but we did reobserve recently fledged chicks from these broods. Chicks from two broods attained flight at 19 and 21 days post-hatch.

Parental Care.-We observed an incubating adult during $93 \%$ of nest checks $(n=$ 181). Incomplete clutches containing 1,2 , or 3 eggs were incubated during 70,83 , and $100 \%$ of nest checks, respectively $(n=10$, $12,13)$, and incubating adults were observed during $95 \%$ of nest checks for completed clutches $(n=46$; samples not independent). We were able to identify which member of the

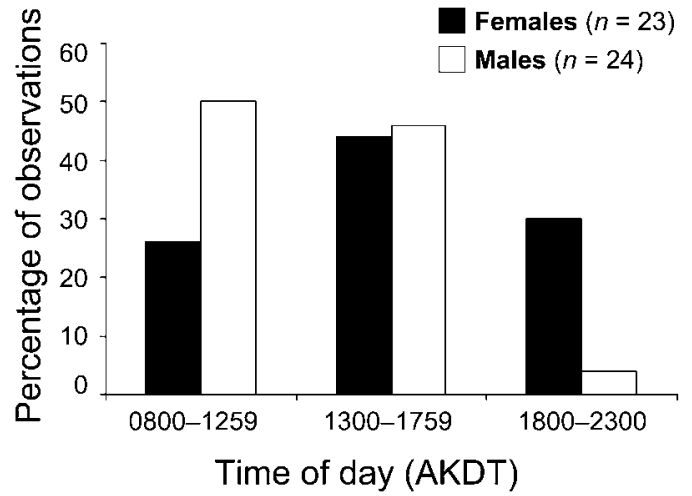

FIG. 2. Incubation patterns for Rock Sandpipers during three diurnal periods on a 48-ha plot on the Yukon-Kuskokwim River Delta, Alaska. Data represent percentage of time males and females were observed tending nests. Temporal incubation pattern was not independent of gender $\left(\chi_{2}^{2}=6.5, P<0.05, n=\right.$ 47).

pair was incubating during 78 nest observations $(n=30$ nests). We randomly selected one observation per bird from each nest ( 23 females, 24 males) from these data, and compared the proportion of birds incubating during three diurnal periods: morning (08001259 hrs AKDT), afternoon (1300-1759 hrs), and evening (1800-2300 hrs). Males regularly incubated clutches during the morning and afternoon and rarely during the evening, whereas female incubation was relatively consistent throughout the day (Fig. 2).

We observed two females being relieved of incubation by their mates. In both cases, the male flew into the general area calling ("song" of Miller et al. 1988, Miller 1996; "complex trill" of Tikhonov 1986) and alighted $\sim 50 \mathrm{~m}$ from the nest. Approaching males then continued toward the nest on foot in rapid bursts that were reminiscent of a plover's (Charadriidae) run-and-stop foraging technique. Males repeatedly called ("cricket call"; Miller 1996) while approaching the nest (30$60 \mathrm{sec}$ ), and continued to call at the nest while performing the Pointing Display (male leans forward from rim of nest, points bill toward ground, and drops wing-tips below plane of tail; Gill et al. 2002). Females left the nest soon after males initiated the Pointing Display (5-15 sec), and males continued calling in the Pointing Display posture for 5-10 sec after female departure. Males immediately chased 
females on foot (2-3 times), after relaxing from the Pointing Display posture, until the female took flight and departed the area. One male pecked his mate on the back while giving chase. Males then settled on the nest and called for 10-15 sec. We observed similar behavior while studying Rock Sandpipers during brood-rearing at another site on the YKD (M. Johnson, pers. obs.). In this case, a parent of unknown gender had been vigilant toward its brood for at least $30 \mathrm{~min}$ (maximum distance to chick $10 \mathrm{~m}$ ) when it began giving the cricket call from the Pointing Display posture. After 30-60 sec of calling, its mate alighted 5 $\mathrm{m}$ away. The calling bird continued to call from the Pointing Display posture in the presence of its mate for $15 \mathrm{sec}$, and then flew 40 $\mathrm{m}$ and began foraging.

We conducted detailed behavioral observations of four broods for $11,12,19$, and 21 days post-hatch (mean number of observations/brood =10). Males cared for young, and two of four females shared in parental duties throughout brood care (19 and 21 days). One female deserted her young and mate at 7 days post-hatch, and her brood was depredated at 12 days post-hatch. Another female deserted immediately after hatch, but we were unable to learn the fate of this brood. Linear distances traveled by parents and young ranged widely. For example, within a day, one brood moved $>300 \mathrm{~m}$ in a 5-hr period while another moved $52 \mathrm{~m}$ in a 9-hr period. Throughout brood care, one brood traveled $2.8 \mathrm{~km}$ during an 11-day period and another traveled $1.3 \mathrm{~km}$ during a 13-day period.

We observed parents brooding chicks on three occasions ( $n=2$ broods), all during the first 5 days post-hatch. Males were vigilant toward the brood for two broods we followed through fledging ( $n=10$ and 16 observations, respectively) during 63 and $80 \%$ of brood observations, while females were vigilant during 75 and $90 \%$ of observations, respectively. The mean maximum distance throughout brood care between vigilant parents and young was $9 \pm 4 \mathrm{~m}(n=26)$. Parents that were not vigilant toward their young generally foraged $>20 \mathrm{~m}$ from the brood's location. There was no correlation between maximum distance between parents and chicks, and the number of days post-hatch $(r=0.21, P=0.18, n=45)$.

Nesting Habitat and Space Use.-We were

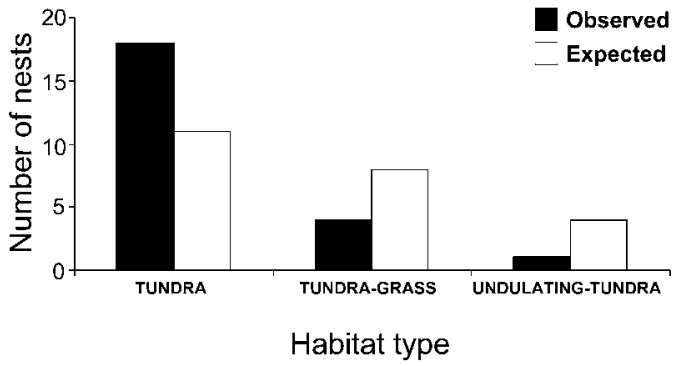

FIG. 3. Number of Rock Sandpiper nests in three habitat patch types on a 48-ha plot on the Yukon Kuskokwim River Delta, Alaska. Habitat use differed from that expected if birds used habitat patches in relation to availability $\left(\chi^{2}{ }_{2}=9.4, P<0.01, n=23\right)$.

able to delineate habitat patch use (tundra, tundra-grass, and undulating-tundra) for 23 nests. Rock Sandpiper nests were more often in tundra and less often in tundra-grass and undulatingtundra than expected if birds used habitat in proportion to availability (Fig. 3). Home range size $(\bar{x} \pm \mathrm{SD})$, from arrival through hatch, ranged from 2 to 12 ha $(2004=6.5 \pm 3.7$ ha, range 1.9-11.8 ha, $n=5 ; 2005=5.7 \pm 2.0$ ha, range 2.9-8.2 ha, $n=7$ ). Females used larger areas than their mates in three of four pairs (female/ male home range size $=6.3,2.0,1.1$, and 0.8 ha). Inter-annual home ranges overlapped between 35 and $64 \%$ ( $n=3$ males, 1 female). Mean distance from a nest to its nearest neighbor nest was $363 \pm 126 \mathrm{~m}$ (range $=162-796$ $\mathrm{m}, n=34$, 1998-2005).

Inter-and Intra-annual Dispersal, Postbreeding Movements, and Migration.-Interannual breeding dispersal distance ranged between 100 and $440 \mathrm{~m}$ for one pair that bred at our study site for 7 consecutive years (mean $=261 \pm 134 \mathrm{~m}$ ). Three pairs bred at the site for 3 consecutive years with median inter-annual dispersal distances of 88, 158, and 288 $\mathrm{m}$ (range $=50-345 \mathrm{~m}$ ), and a pair that bred at our study site for two consecutive seasons moved $517 \mathrm{~m}$ between years. We measured inter-annual breeding dispersal distance for pairs at 12 nests of known fate. Failed pairs $(n=10)$ had a mean nest dispersal distance of $247 \pm 40 \mathrm{~m}$ (range $=70-517 \mathrm{~m})$, and successful nests $(n=2)$ had subsequent nest dispersal distances of 50 and $165 \mathrm{~m}$. Mean intraannual dispersal distance (distance between first and second nesting attempts within a 
year) was $210 \pm 124 \mathrm{~m}(n=8$, range $=37-$ $385 \mathrm{~m})$.

Two banded individuals were observed away from the study site. A female banded in 2003 returned and bred with the same mate in 2004. She was subsequently observed on 13 April 2005 in Prince William Sound (D. M. Troy, pers. comm.), $>900 \mathrm{~km}$ east-southeast of the study site. She was observed on our study plot paired with her prior mate on 12 May 2005 and we found her partially consumed body on 15 May 2005. A male banded with its mate in 2003 was reobserved among flocks of post-breeding birds $27 \mathrm{~km}$ southwest of the study site near the mouth of the Manokinak River on 24 July 2003, 2 August 2006, and 3 August 2007 (D. J. Rizzolo, pers. comm.).

\section{DISCUSSION}

We provide the first description of behavior and reproductive success among marked Rock Sandpipers in North America. Kondratyev (1982) and Tomkovich $(1985,1994)$ reported on the behavior of this same subspecies from a color-marked population on the Chukotsky Peninsula, Russia. The life history of migratory shorebirds is generally characterized by delayed maturity, low productivity, and relatively high adult survivorship (Evans and Pienkowski 1984, Piersma and Baker 2000). Our results for Rock Sandpipers breeding on the YKD are consistent with this pattern as were previous reports from Chukotka, Russia.

Annual return rates offer a minimum estimate of survival and are the product of four probabilities (true survival, site fidelity, site propensity, and true detection). If return rates are high, true survival and all of the three other probabilities must be higher (Sandercock 2006). It appears that C. p. tschuktschorum has relatively high annual survival based on high annual return rates observed on the Chukotsky Peninsula (68-79\%; Tomkovich 1994) and in this study (67-100\%). However, reproductive success varied considerably between Alaska and Chukotka, Russia. We estimated that $\sim 12 \%$ of females that initiated clutches at our study site successfully fledged offspring on an annual basis, whereas $42 \%$ of females nesting on the Chukotsky Peninsula fledged young (P. S. Tomkovich in Gill et al. 2002). Differences among these estimates may reflect temporal and/or geographic variation in reproduction, but we are unable to speculate on temporal differences because the studies were not contemporary. However, it does not appear that latitudinal difference between the two sites resulted in differences in estimated reproductive rates. Rock Sandpipers breeding in Chukotka were four degrees latitude farther north than our study site and experienced shorter breeding seasons (clutches initiated over a 29 and 43 day period in Chukotka and on the YKD, respectively) with higher reproductive rates. Another possible explanation for variation in reproductive rates is that predator densities and/or community compositions vary between the two sites. Additional study is required to learn if these estimates accurately depict natural variation in reproductive rates within the two regions, and, what factors contribute most significantly to the differences.

We observed higher apparent nest success among second nests compared to initial nesting attempts. This was surprising given that nest survival often decreases across the nesting season for many avian species (Perrins 1970, Daan et al. 1989). Daily survival rates of Western Sandpiper (Calidris mauri) nests at our study site gradually declined until just past midseason and rose slightly during the last part of the breeding season (Johnson and Walters 2008). Seasonal variation in daily nest survival rates was only evident among pairs breeding at the site for their first or second season (i.e., recent immigrants or young birds). In contrast, daily nest survival rates were relatively constant across the nesting season for Western Sandpiper pairs with 2 or more years of prior site experience (Johnson and Walters 2008). Higher apparent nest success for Rock Sandpipers among second nests may be the result of older birds or those with prior site experience renesting more frequently compared to younger birds or recent immigrants.

Parental care is apparently variable within C. p. tschuktschorum as Alaskan and Chukotkan breeding birds differed in onset of incubation, and nest and brood attendance patterns. P. S. Tomkovich (in Gill et al. 2002) reported that full-time incubation begins with the laying of the last egg (only 13-37\% of incomplete clutches were warm and/or attended by adults). In contrast, we observed incu- 
bating adults during $>70 \%$ of nest checks prior to clutch completion. One parent assumed full responsibility of incubation in some pairs breeding on the Chukotsky Peninsula, while in others parents shared incubation duties (Kondratyev 1980, 1982; P. S. Tomkovich in Gill et al. 2002). We did not observe an adult deserting its mate during incubation, but females did desert during brood care. Further, $54 \%$ of Rock Sandpiper broods were tended by a single adult at another YKD site (Johnson and McCaffery 2004). Maternal-only care was observed on the Chukotsky Peninsula for $20 \%$ of broods, and no broods received biparental care after 9 days post-hatch (Gill et al. 2002).

Adult home range size prior to hatch averaged 5.7-6.5 ha at our study site, and females used a larger area compared to their mate. These estimates are similar to those reported at Chukotka where mean nesting territory size was 5.2 ha (range $3.0-8.0, n=19$ ). Parents and broods traveled hundreds of meters within a few hours post-hatch and $1+\mathrm{km}$ throughout brood care. These results are consistent with previous studies on the YKD (Johnson and McCaffery 2004) and the Chukotsky Peninsula (mean distance from the nest during the third week post-hatching $=747 \mathrm{~m}, n=6$, Tomkovich 1985). The ecology of Rock Sandpiper chicks is dynamic during the first weeks of life. Chicks generally leave the nest within 12 hrs of hatching and forage independently (P. S. Tomkovich in Gill et al. 2002). Brood movement patterns and habitat use likely indicate parental efforts to increase survival of young by directing them to resources such as food and shelter, and alerting them to the presence of predators (Johnson et al. 2008).

The distance that post-breeding Rock Sandpipers move during molt-migration is highly variable among and within subspecies; most populations undergo molt at coastal sites (Gill et al. 2002). C. p. tschuktschorum breeding on YKD generally move only a few kilometers to molting areas while those nesting on Chukotsky Peninsula may travel $600 \mathrm{~km}$ to the same sites (Gill et al. 2002). A male banded at our study site was observed in three nonconsecutive seasons at the same post-breeding site. The mate of this male was reobserved annually on our study site, but she was not observed at his molting site. Rock Sandpiper fidelity to molting areas also has been observed at other sites on the YKD (B. J. McCaffery and R. E. Gill Jr., pers. obs.).

Environmental variation across breeding areas (seasonal, climatic, landscape) contribute to the polytypic nature of Rock Sandpipers (Pruett and Winker 2005). Variation in parental care patterns and reproductive rates between two study sites in Alaska and Chukotka, Russia suggests that variation within Beringia may not be limited to morphological characters, but may extend into behavioral and demographical parameters as well. Additional study will be required to confirm whether or not the site-specific differences described here truly reflect consistent regional differences in Rock Sandpiper breeding biology.

\section{ACKNOWLEDGMENTS}

We thank the staff of the Yukon Delta National Wildlife Refuge for supporting this research. Financial support was received from the U.S. Fish and Wildlife Service, the Harold F. Bailey Fund at Virginia Tech, and the U.S. Geological Survey Forest and Rangeland Ecosystem Science Center. We also thank T. L. Booms, C. E. Fitzpatrick, P. N. Laver, A. C. Niehaus, D. J. Rizzolo, D. R. Ruthrauff, and M. K. Spies for assistance in the field, and R. E. Gill, L. W. Oring, P. M. Sanzenbacher, T. A. Sordahl, and P. S. Tomkovich for comments on earlier drafts of this manuscript. Any use of trade, or firm names is for descriptive purposes only and does not imply endorsement by the U.S. Government.

\section{LITERATURE CITED}

Altmann, J. 1974. Observational study of behavior: sampling methods. Behaviour 48:227-265.

AMERICAN ORnithologists' Union (AOU). 1957. Check-list of North American birds. Fifth Edition. American Ornithologists' Union, Baltimore, Maryland, USA.

Baldwin, S. P., H. C. Oberholser, AND L. G. Worley. 1931. Measurements of birds. Scientific Publications of the Cleveland Museum of Natural History 2:1-165.

Bent, A. C. 1927. Life histories of North American shore birds, Part 1. U.S. National Museum Bulletin Number 142.

Boland, J. M. 1990. Leapfrog migration in North American shorebirds: intra- and interspecific examples. Condor 92:284-290.

Brown, S., C. Hickey, B. Harrington, and R. Gill. 2001. The U.S. Shorebird Conservation Plan, Second edition. Manomet Center for Conservation Sciences, Manomet, Massachusetts, USA.

Conover, H. B. 1944. The North Pacific allies of the Purple Sandpiper. Field Museum of Natural History Zoological Series Number 29. 
Cramp, S. And K. E. L. Simmons. 1983. The birds of the Western Palearctic. Volume 3. Waders to gulls. Oxford University Press, Oxford, United Kingdom.

DaAn, S., C. Dijkstra, R. Drent, And T. Meijer. 1989. Food supply and the annual timing of avian reproduction. Proceedings of the International Ornithological Congress 19:392-407.

Evans, P. R. AND M. W. PienKowski. 1984. Population dynamics of shorebirds. Pages 83-123 in Behaviour of marine animals, current perspectives in research. Volume 5 (J. Burger and B. L. Olla, Editors). Plenum Press, New York, USA.

GILL JR., R. E. 1997. Rock Sandpipers wintering in Cook Inlet, Alaska. Field Notes 51:786-787.

Gill JR., R. E. AND C. M. HANDEl. 1990. The importance of subarctic intertidal habitats to shorebirds: a study of the central Yukon-Kuskokwim Delta, Alaska. Condor 92:709-725.

GiLl JR., R. E. AND P. D. JorgENSEN. 1979. A preliminary assessment of timing and migration of shorebirds along the north central Alaska Peninsula. Studies in Avian Biology 2:110-120.

Gill JR., R. E. AND T. L. TibBitTs. 1999. Seasonal shorebird use of intertidal habitat in Cook Inlet, Alaska. Final Report. USDI, Geological Survey, Biological Resources Division, and OCS Study, MMS 99-0012. Anchorage, Alaska, USA.

Gill, R. E., P. S. Tomkovich, AND B. J. McCaffery. 2002. Rock Sandpiper (Calidris ptilocnemis). The birds of North America. Number 686.

Hanna, G. D. 1921. The Pribilof Sandpiper. Condor 23:50-57.

JoHnson, D. H. 1979. Estimating nest success: the Mayfield method and an alternative. Auk 96:651661.

Johnson, M. 2006. Demography and behavior of Western Sandpipers (Calidris mauri) breeding on the Yukon-Kuskokwim River Delta, Alaska. Dissertation. Virginia Polytechnic Institute and State University, Blacksburg, USA.

JoHnson, M. AND B. MCCAFFERY. 2004. Use of upland tundra habitats by Western and Rock sandpipers during brood-rearing on the Yukon-Kuskokwim Delta, Alaska. Wader Study Group Bulletin 103: 36-39.

JoHNSON, M. AND J. R. WALters. 2008. Effects of mate and site fidelity on nest survival of Western Sandpipers (Calidris mauri). Auk 125:76-86.

Johnson, M., S. Aref, AND J. R. WAlters. 2008. Parent-offspring communication in the Western Sandpiper. Behavioral Ecology 19:489-501.

KondRatYeV, A. Y. 1980. On warming regimes of wader clutches. Pages 20-22 in News in studies of waders (V. E. Flint, Editor). Nauka Publishing, Moscow, Russia.

Kondratyev, A. Y. 1982. Biology of shorebirds in tundras of north-eastern Asia. Nauka Publishing, Moscow, Russia.

MAYFIELD, H. 1961. Nesting success calculated from exposure. Wilson Bulletin 73:255-261.
MAYFIELD, H. 1975. Suggestions for calculating nest success. Wilson Bulletin 87:456-466.

MilLer, E. H. 1996. Acoustic differentiation and speciation in shorebirds. Pages 241-257 in Ecology and evolution of acoustic communication in birds (D. E. Kroodsma and E. H. Miller, Editors). Comstock Publishing Associates, Ithaca, New York, USA.

Miller, E. H., W. W. H. GunN, AND B. N. Veprintsev. 1988. Breeding vocalizations of Baird's Sandpiper Calidris bairdii and related species, with remarks on phylogeny and adaptation. Ornis Scandinavica 19:257-267.

MoHR, C. O. 1947. Table of equivalent populations of North American small mammals. American Midland Naturalist 37:223-249.

Morrison, R. I. G., B. J. McCAFFERy, R. E. Gill, S K. Skagen, S. L. Jones, G. W. Page, C. L. GratTON-TRevor, AND B. A. ANDREs. 2006. Population estimates of North American shorebirds, 2006. Wader Study Group Bulletin 111:67-85.

Myers, J. P., O. Hildén, AND P. TOMKOVICH. 1982. Exotic Calidris species of the Siberian tundra. Ornis Fennica 59:175-182.

PERrins, C. M. 1970. The timing of birds' breeding season. Ibis 112:242-255.

Piersma, T. AND A. J. BaKer. 2000. Life history characteristics and the conservation of migratory shorebirds. Pages 105-124 in Behaviour and conservation (L. M. Gosling and W. J. Sutherland, Editors). Cambridge University Press, Cambridge, United Kingdom.

Preble, E. A. AND W. L. McAtee. 1923. Birds and mammals of the Pribilof Islands, Alaska. North American Fauna 46.

Pruett, C. L. AND K. WinKer. 2005. Biological impacts of climatic change on a Beringian endemic: cryptic refugia in the establishment and differentiation of the Rock Sandpiper (Calidris ptilocnemis). Climatic Change 68:219-240.

SANDERCOCK, B. K. 2006. Estimation of demographic parameters from live-encounter data: a summary review. Journal of Wildlife Management 70: $1504-1520$.

Seaman, D. E., J. J. Millspaugh, B. J. Kernohan, G. C. Brundige, K. J. Raedeke, and R. A. Gitzen. 1999. Effects of sample size on kernel home range estimates. Journal of Wildlife Management 63: 739-747.

Sibley, C. G. AND B. L. Monroe JR. 1990. Distribution and taxonomy of birds of the world. Yale University Press, New Haven, Connecticut, USA.

SMith, W. 1952. The food habits of a population of Black Turnstones, Rock Sandpipers, and Surfbirds wintering in southern British Columbia. Dissertation. University of British Columbia, Victoria, Canada.

Stiles, F. G. and D. L. Altshuler. 2004. Conflicting terminology for wing measurements in ornithology and aerodynamics. Auk 121:973-976.

Tikhonov, A. V. 1986. Acoustic signaling and behav- 
ioral ecology of birds. Moscow State University Publishing, Moscow, Russia.

Tomkovich, P. S. 1982. Sexual dimorphism of the Rock Sandpiper Calidris ptilocnemis (Charadriidae). Zoologicheskij Zhurnal 61:1110-1113.

TомкоVICH, P. S. 1985. Territoriality of some monogamous species of Calidridinae sandpipers. Proceedings of the 18th International Ornithological Congress. Volume 2 (V. D. Liyichev and V. M. Garilov, Editors). Nauka Publishing, Moscow, Russia.

TomKovich, P. S. 1994. Site Fidelity and spatial structure of populations in the Rock Sandpiper Calidris ptilocnemis and Dunlin Calidris alpina on Chukotsky Peninsula. Russian Journal of Ornithology 3:13-30.

Tomkovich, P. S. 2003. Parental care in the Rock Sandpiper Calidris ptilocnemis on Chukotsky Peninsula, Russia. Russian Journal of Ornithology 12:179-183.

U.S. Shorebird Conservation Plan (USSCP). 2004. High priority shorebirds-2004. Unpublished Report. USDI, Fish and Wildlife Service, Arlington, Virginia, USA.

ZAR, J. H. 1999. Biostatistical analysis. Prentice Hall, Upper Saddle River, New Jersey, USA 